IZA DP No. 7909

The Poor and the Poorest, Fifty Years On

Ian Gazeley

Andrew Newell

Kevin Reynolds

Rebecca Searle

January 2014 


\title{
The Poor and the Poorest, Fifty Years On
}

\author{
Ian Gazeley \\ University of Sussex
}

Andrew Newell

University of Sussex

and IZA

Kevin Reynolds

University of Sussex

Rebecca Searle

University of Sussex

\section{Discussion Paper No. 7909 \\ January 2014}

IZA

\author{
P.O. Box 7240 \\ 53072 Bonn \\ Germany
}

\author{
Phone: +49-228-3894-0 \\ Fax: +49-228-3894-180 \\ E-mail: iza@iza.org
}

\begin{abstract}
Any opinions expressed here are those of the author(s) and not those of IZA. Research published in this series may include views on policy, but the institute itself takes no institutional policy positions. The IZA research network is committed to the IZA Guiding Principles of Research Integrity.

The Institute for the Study of Labor (IZA) in Bonn is a local and virtual international research center and a place of communication between science, politics and business. IZA is an independent nonprofit organization supported by Deutsche Post Foundation. The center is associated with the University of Bonn and offers a stimulating research environment through its international network, workshops and conferences, data service, project support, research visits and doctoral program. IZA engages in (i) original and internationally competitive research in all fields of labor economics, (ii) development of policy concepts, and (iii) dissemination of research results and concepts to the interested public.
\end{abstract}

IZA Discussion Papers often represent preliminary work and are circulated to encourage discussion. Citation of such a paper should account for its provisional character. A revised version may be available directly from the author. 
IZA Discussion Paper No. 7909

January 2014

\section{ABSTRACT}

\section{The Poor and the Poorest, Fifty Years On}

We re-explore Able-Smith and Townsend's landmark study of poverty in early post WW2 Britain. They found a large increase in poverty between 1953-4 and 1960, a period of relatively strong economic growth. Our re-examination is a first exploitation of the newlydigitised Board of Trade Household Expenditure Survey data set for 1953/4. Able-Smith and Townsend used only a small part of this data source. We find that Able-Smith and Townsend substantially over-estimated the rise in absolute poverty and also substantially underestimated the rise in relative poverty. Their and our findings on poverty reflect a large rise inequality in the distribution of expenditure among British households. This rise is related to a rise in the preponderance of pensioner households, who, for instance, account for all the poor households in the 1961 Family Expenditure survey.

JEL Classification: N34, I32, J12

Keywords: $\quad$ poverty, inequality 1950s, Britain

Corresponding author:

Andrew Newell

Department of Economics

University of Sussex

Brighton, BN1 9SL

United Kingdom

E-mail: a.t.newell@sussex.ac.uk 


\section{Introduction}

In 1965 Brian Abel-Smith and Peter Townsend published their seminal study of poverty in post-war Britain. The central finding of the Poor and the Poorest was that the Beveridge welfare state had not eliminated poverty, indeed the authors found a re-emergence of poverty over the latter part of the 1950s. Their central estimates, which they presented with circumspection due to various data issues, were that the proportion of households below the poverty line increased from 10.1 per cent in $1953 / 4$ to $17.9 \%$ in $1960 .{ }^{1}$ They estimated that this represented an increase in the number of people in poverty from about 4 million in 1953/4 to 7.5 million in 1960. According to Abel-Smith and Townsend (hereafter A-S\&T), poverty was disproportionately concentrated in one-person households (particularly among the retired) and also in large households with more than six persons.

Their findings cast a shadow of doubt over the contemporary perception of post-war prosperity. Since the end of the Second World War there had been good reason to be optimistic: the 1945-51 Labour Governments had introduced a 'cradle to grave' welfare state; Rowntree's third survey of poverty in York in 1951 had found the almost complete elimination of the type of deprivation he had documented in previous enquiries - an improvement that he largely assigned to the welfare state; real average earnings had increased by about 50 per cent in the twenty years following the end of the war and unemployment had remained below even the most optimistic levels of Beveridge and Keynes' full employment benchmarks. The Poor and the Poorest undermined the complacency surrounding the success of this post-war social democratic project and had a direct impact on the social policy agenda of the 1960s. It was, for example, directly responsible for the formation of the Child Poverty Action Group and strengthened considerably contemporary concern for the plight of the elderly in society.

A-S\&T's conclusions were based upon the analysis of a sample of the returns to the 1953/4 and 1960 Ministry of Labour household expenditure surveys. It is now commonplace to use household expenditure survey evidence to address questions of inequality and poverty. AS\&T were early exponents of this approach and were granted access to the results of the 1953/4 and 1960 enquiries by the Ministry of Labour. In The Poor and the Poorest they employed a definition of poverty that was explicitly relative. Their preferred poverty line was taken to be 140 per cent of the current National Assistance level. Defining poverty in relation to benefit levels had its genesis in a series of academic enquiries emanating from the Department of Social Administration (now Social Policy) at The London School of Economics in the early 1960s. Such an approach marked a discrete break with the earlier English social scientific tradition of a physiological minimum needs based approach.

This article is a re-evaluation of their findings. It utilises the full survey results from the 1953/4 and 1961 Ministry of Labour enquires (12,900 and 3,500 households respectively),

\footnotetext{
${ }^{1}$ This result was widely accepted, see Frank R. Bruel 'Review of Able-Smith and Townsend Poor and the Poorest', Social Service Review, Vol 40, No 3 September 1996) '... it is rather surprising and disappointing to find that about 10 per cent of the population in 1953-4 and 15 per cent in 1960 are estimated to be in poverty...'
} 
attempts to correct for the known biases in these surveys so as to make them more representative and employs a number of measures of poverty and inequality to make comparison with earlier and later findings. Unlike A-S\&T, we are able to make a smooth comparison between 1953/4 and 1961 using total household expenditure (Abel-Smith and Townsend compared household expenditure in 1953/4 with income in 1960). This article is set out as follows: in section 1 we describe the 1953/4 survey and discuss the sample of these data selected by A-S\&T; in section 2 we present our estimates from the full and compare with those given in the Poor and the Poorest; section 3 reviews the 1960 household expenditure survey and discusses A-S\&T's findings; section 4 describes the 1961 household expenditure survey and our analysis of these data. We also compare our results from the full 1961 survey with A-S\&T's sample from the 1960 survey; section 5 reviews their choice of poverty line and recalculates poverty based on a number of additional measures. We also present global estimates of inequality and place these in the context of the existing time-series of inequality estimates for post-war Britain derived from household expenditure survey evidence.

\section{Abel-Smith and Townsend's results for 1953/4}

A-S\&T's estimates of poverty utilised the data from the Ministry of Labour 1953/4 household expenditure survey. This survey was commissioned to provide the information required to update the official cost of living index. The last household expenditure survey was carried out in 1937/8, which was restricted to 10,762 working class households. A smaller enquiry of middle-class households was conducted at the same time. The Cost of Living Advisory Committee was formed in 1946 and recommended adjustments to the official COL index, known as the Interim Cost of Living Index in 1947, as the official index was based upon a limited basket of goods that were inappropriately weighted. In 1951 the Committee made a recommendation for an entirely new survey of household expenditure, as soon as conditions allowed. By 1953/4 it was judged that this moment had arrived: price controls had been substantially reduced, the rationing of clothes and most household goods had already ended and food rationing was scheduled to end.

The new Cost of Living index was designed to be 'representative of the expenditures of practically all wage earners and moderate salary earners', with a target group where the Head of Household was earning between $£ 150$ and 1,000 per annum. It was recognised that the survey used to evidence expenditures had a value beyond the needs of Cost of Living index revision and was designed to cover the whole community, not just the target group. To ensure that this objective was met, the survey sample was a two-stage random sample selected from addresses from local rating lists (the nearest complete list of all private households). In the first stage, 378 regional rating lists were selected from approximately 1,800, which covered all larger urban areas and a selection of smaller urban and rural areas. In total these lists covered about 60 per cent of the UK population. In the second stage, households were randomly selected from these lists to give an objective sample size of 10,000 households. Given the likely response rate, it was considered necessary to select a gross sample of 20,000 
households. The response rate in practice was slightly better than anticipated and the gross sample produced 12,911 household returns.

The survey was carried out by interview and $£ 1$ was paid for complete returns. Details were collected of household structure and characteristics, income (including welfare payments), household and individual expenditure on a daily basis for a three consecutive week period. The survey was organised into five sections (HB1-HB5): HB1 identified the household by name and address and provided summary information regarding household age and composition and employment details etc.; HB2 recorded details of household expenditure on housing and fuel; HB3 covered personal tax, licences and insurance; HB4 recorded individual daily expenditures and HB5 individual wages or salaries and benefits, including benefits in kind. These forms were fixed format design except for HB4, which was free format. The data recorded was checked by a Ministry official at interview, but subsequently a significant amount of re-ordering and checking was carried out by the Ministry, including assigning unique codes to expenditures recorded in HB4 (HQ codes) and the regularisation of most recorded food quantities. In addition, the information recorded in HB1 was de-personalised and transferred to HB20. HB1 was subsequently destroyed. To ascertain seasonal expenditures, the survey timing was staged, commencing on $26^{\text {th }}$ January 1953 and ending in early 1954. Thus the 1953/4 household expenditure survey is the most complex of the twentieth century and is unique in collecting details of daily individual expenditures.

Because of the complexities of the survey, and a lack of resources, A-S\&T sampled returns from the poorest income groups and those households with the largest family size included in the 1953/4 survey. In addition, they were advised that the income figures for this survey were unreliable and that they should work with total household expenditure (1965:21). They employed a generous definition of expenditure, which encompassed recorded daily expenditures, plus all forms of irregular expenditure recorded in the survey, such as housing, fuel insurance, education and taxes. From the 12,911 households in the survey, Abel-Smith and Townsend selected 5,633. These were chosen on the basis of large household size and low weekly expenditure groups (where total expenditure was less that $£ 14$ per week for large households). From this target group of low expenditure/large households, A-S\&T took a 25 per cent random sample and were thus able to analyse 1,408 households in detail. Total household expenditure was not recorded in the survey and has to be calculated from the sum of all individual and household expenditures. The precise nature of their sample is set out in Table 1.

$<$ Insert Table 1 about here >

A-S\&T applied two poverty lines. Their preferred measure was 140 per cent of the current National Assistance scale (plus housing costs), but they also used Rowntree and Lavers 1950 York poverty line adjusted for 1953 prices. Full details are provided in Appendix 1. They make a strong case for a relative measure of poverty, rather than one based upon 
physiological minimum requirements: 'The approach which we have adopted follows the principle that the minimum level of living regarded as acceptable by a society increases with national prosperity.' (1965:19). As a consequence, their headline findings on poverty and how it changed between 1953/4 and 1960 are all based upon the application of National Assistance scale poverty-line. We discuss the implications of this poverty measure for identifying changes in poverty more fully in section 5 .

\section{$<$ Insert Table 2 about here >}

A-S\&T's results for 1953/4 are reported in Table 2. For their sample, this sets out the percentage and numbers of households relative to the current National Assistance scale, along with estimates of the total number of persons in these categories for the UK as a whole. Their headline finding of $10.1 \%$ of households below 140 per cent of National Assistance is the cumulative percentage of the figures given in Column (3), up to and including 130-139 per cent of National Assistance plus housing costs. A-S\&T estimated that this represented just fewer than 4 million persons in the UK in 1953/4 (3.948 million from Column (7)). The poor were disproportionately concentrated in small households, as Table 3 shows.

\section{$<$ Insert Table 3 about here >}

\section{Re-evaluating $1953 / 4$}

We have recently extracted the data from all the surviving returns from the 1953/4 survey (12,903 households). A small number of these surveys were found to be problematic or incomplete is some way, but essentially we are able to re-estimate A-S\&T's calculations on almost the entire survey, employing the same assumptions with respect to household composition (see Appendix 2). Weekly expenditure variables are the average of all daily individual expenditures recorded in HB4 over the three-week collection period, plus individual and household expenditures recorded in HB2, 3 and 5. Table 4 provides some descriptive statistics and Chart 1 reports a histogram of total household expenditure relative to the National Assistance rate from this data.

\section{$<$ Insert Table 4 and Chart 1 about here >}

Notice in Table 4 reported mean household income is significantly less than recorded mean total household expenditure. This is often the case with household expenditure survey data 
(see Deaton 1997: 26-32), but in this case, it is also worth noting a systematic bias. Around 700 households declined to report household income (though these households were assigned to an income category by the Ministry, which is recorded), and these were disproportionately concentrated in low income groups, thus vindicating the advice provided by the Ministry to Townsend to work with total household expenditure. Mean household size is 3.17 (Table 4 column 1), and the mean size of all households with school age children is 4.26 (Table 4 column 2). Mean total household expenditure is roughly 3 times prevailing National Assistance rates (Chart 1), with a small tail to the left of the distribution where total expenditure is equal to or lower than 2 times National Assistance. Using A-S\&T's poverty line set 140 per cent of each household's National Assistance basic entitlement (plus housing expenditures), which we discuss further in section 3 below, we estimate an overall poverty rate of 10.1 per cent on the entire survey, which accords exactly with A-S\&Ts estimate from their sample of 10.1 per cent. This result is explored in more detail in section 4 where we assess differences between our findings and those of A-S\&T. However we should make it clear there are many differences between our methods and those of A-S\&T, and so the exact similarity between the estimates is something of a co-incidence. The main difference is that we use all the data and A-S\&T only used a $25 \%$ random sample from the poorest households, so, in the end, little more that $11 \%$ of the whole data set. Also, inevitably, there will have been errors in their methods, and it is impossible to rule out, some errors remaining in our electronic version of the data ${ }^{2}$. A-S\&T report (op. cit. page 28) finding 316 low expenditure households from their sample. This multiplies by 4 to an estimate of 1,264. We find 1,261 low expenditure households using the full digitised sample. When we try to restrict our sample to their low income group, we find a slightly fewer low income households, with a slightly lower poverty rate, than they report, and 37 low expenditure households that fall outside their low income groupings. All in all, if this were simple replication study, we would conclude that A-S\&T had almost certainly reported their methods and performed their analysis very accurately.

Here we establish, prior to digging deeper into the results, the relationships between this poverty measure and household and head of household characteristics (including household structure and composition, occupation, labour market status and welfare dependency).

\section{$<$ Insert Table 5 about here >}

Table 5 shows that disproportional amounts of poverty are estimated to exist among households comprising single persons, both men and women. Also there are high levels of poverty and a great concentration of the poor in households without work. Job seeker-headed households and those with heads of household on sick benefits have high poverty rate, but these are a relatively small groups. By contrast 45 per cent of poor households receive 75 per cent of their income from State Old Age Pension (SOAP) plus National Assistance. This is

\footnotetext{
${ }^{2}$ http://www.sussex.ac.uk/britishlivingstandards/surveys/1953-4.
} 
perhaps not surprising given the definition of poverty at $140 \%$ of NA rate, but the large groups of households spending between 500d and maybe 1500d per week, roughly £2-£6, does suggest that bulk of poverty is among people on SOAP and National Assistance. In the final part of Table 5 we describe the overall relationship between poverty and household size. As can be seen from this Table, as A-S\&T concluded from the analysis of their sample, poverty was indeed concentrated in one-person households (mainly those in receipt of SOAP) and among large households with 6 persons or more.

\section{Re-estimating poverty in the early 1960s using $1961 \mathrm{FES}$ data}

In this section we re-estimate the difference in the estimated rate of poverty among households between the 1953-4 household expenditure survey (HES) and FES surveys for the 1961, using, as far as we are able, the same methodology as A-S\&T. For the 1960 Family Expenditure Survey they worked with the entire 3,540 households surveyed. At the time of writing, the data from 1960 FES returns have not been digitised, but the data from the 1961 FES are available (3,467 households), so we use these for the comparison. Using 1961 rather than 1960 survey results should make little difference to our ability to re-work A-S\&T, as the surveys were of similar size and collected using identical sample methods. ONS data give a rise of 2.8\% in real household final consumption expenditure between 1960 and 1961 . This is a substantial growth rate, and should, other things equal, lower absolute poverty, but we should also note that the same aggregate grew by $22.9 \%$ between 1954 and $1960,{ }^{3}$ so that the change between 1960 and 1961 is relatively minor.

A-S\&T (1965, pp.17-18) created a poverty standard by applying the basic rate of National Assistance that would be due to each household and then added actual housing costs, since these were usually paid additionally to National Assistance recipients. They chose to set their poverty line for each household at 1.4 times this standard. Their reason for this multiplier is, briefly, that most National Assistance recipients would have received additional payments, in the form of pensions that were not taken into account when entitlements were calculated, for some disabilities, and for occasional extra expenditures, on clothing, for instance. Table 6 gives the National Assistance basic rates that applied at the time of each survey. Note the money values of National Assistance allowances increased by around fifty per cent over the period, but the underlying household equivalence scale changed very little. We employed these scales and information on household structure to compute weekly basic National Assistance levels for all households in both surveys, and then add actual weekly housing costs, that is, rent, rates and, where appropriate, mortgage interest payments to replicate the standard for each household. For the 1953/4 HES, the information on household membership is not complete enough to apply the scales exactly, and so we followed A-S\&T's assumptions as closely as possible (op. cit: 68-9 and Appendix 2).

\footnotetext{
${ }^{3}$ http://www.ons.gov.uk/ons/rel/naa1-rd/united-kingdom-economic-accounts/q1-2013/tsd-united-kingdomeconomic-accounts-q1-2013.html
} 
A-S\&T (op. cit: 20-1) discuss the representativeness of the 1953-4 HES and 1960 FES surveys. They note that households headed by the sick and elderly were under-represented, especially in the 1953-4 HES survey. We will return to this issue below, since it has clear potential to affect for poverty rate comparisons. With this in mind, turn to Table 7, which gives some descriptive statistics for total weekly expenditure and the A-S\&T's poverty standard for both of data sets. There are several important points to note. First, total (nominal) weekly expenditure was $137 \%$ higher on average in the 1961 data. By contrast the poverty standard rose less. This partially reflects the much smaller, (around 50\%), increase in the basic National Assistance allowance, offset by the fact that housing expenditures kept pace with total expenditure, leaving an overall estimated rise in the index of about $100 \%$. There is clear evidence of changes in the cross-section variance of household expenditure, with higher $\log$ variance, $90 / 10$ and $50 / 10$ ratios in 1961 compared to $1953 / 4$. It is notable that the variation in poverty standard across households is also greater in the 1961 data than in the 1953/4 data. This reflects a greater diversity in types of households in the 1961 data, since we have already noted that the relevant National Assistance equivalence scale was more-or-less the same for the two surveys.

\section{$<$ Inset Table 7 about here $>$}

A-S\&T compared total weekly expenditure with their National Assistance-based poverty standard for each household in their selection from the 1953-4 survey returns and estimated that $10.1 \%$ of households spent below 1.4 times their standard. They considered this a lower bound estimate of poverty, due to their empirical approach of working with a lowexpenditure sub-sample. They chose to compare their standard with expenditure rather than income for the 1953/4 FES because they considered the recorded incomes to be less reliable (op. cit., page 21). However, for the 1960 FES data, A-S\&T chose to employ the income data, because the questionnaire asked respondents to distinguish actual income in the reference period from regular income. Employing the income data saved a great deal of computational effort, an important consideration at the time. They found that $17.9 \%$ of households in the 1960 FES had incomes below 1.4 times their standard. The difference between these two findings, suggesting greater poverty in 1961 than in 1953-4 became the key result of their study, driving many of their conclusions, (1965: 63-7).

The version of the 1961 FES data set available at the UK Data Archive has all income information removed, so our approach is a little different. We calculate expenditure-based poverty rates for the full 1953/4 HES data and for the 1961 FES data. We also estimate income-based and expenditure-based poverty rates for 1953/4 HES, using all the recorded incomes, which are consistent across the two parts of the questionnaire that request income information. By so doing, we drop 586 households, or 4.6\% from the sample. Our results are reported in Table 8. 
As already mentioned we find the same proportion (10.1 percent) expenditure-based poverty in the 1953-4 HES as A-S\&T found. We also find substantially lower poverty $(13.8 \%$ compared with 17.9\%) in the 1961 FES than A-S\&T found in the 1960 FES.

\section{Investigating the differences between our estimates and those of A-S\&T.}

Our lower estimate for the early 1960s requires explanation. The most obvious difference between the two estimates is the choice of income versus expenditure as a basis for measurement. There are very well-known differences in reporting biases for expenditure and income and these tend to result in income-based poverty measures being greater than those based upon expenditure (Deaton, 1997: 148). To check this, we re-estimate poverty for 1953-4 HES using income rather than expenditure and find a much higher estimate, see Table 8, row 2. This is clearly a key component in the explanation of why A-S\&T found a steeper rise in the poverty rate then we do.

Now, even if, as our findings suggest, A-S\&T's results on rising poverty were exaggerated by a comparison of income and expenditure-based measures, our evidence still supports their view that there was greater absolute poverty in the early 1960s data. Even in retrospect, this is an initially surprising finding. The latter part of the 1950s was a period of macroeconomic progress, as we have documented, so, on that basis alone, increased poverty would not be predicted. This is especially true with respect to A-S\&T's poverty standard that was, as we have demonstrated, declining against average household expenditure.

\section{$<$ Insert Chart 2 here $>$}

Why was poverty higher in the 1961 data set? The two histograms in Charts 1 and 2 illustrate the distributions of expenditure divided by the poverty standard in the two samples. This ratio is roughly proportional to single male adult equivalent household expenditure ${ }^{4}$. In both graphs, a heavy vertical line is placed at 1.4, representing the poverty line. Note first the appearance of greater density below the poverty line in the 1961 data. We saw in Table 7 that the variances of log total expenditure and of the log poverty standard were both greater in the 1961 data set than in the 1953/4 data set. The standard deviation of the log of the ratio of the two variables rises from 0.45 for $1953 / 4$ to 0.64 for 1961 . So, the increased variance in this ratio, roughly adult equivalent expenditures, derives from both increased expenditure variance and from increased variation in household structures. ${ }^{5}$ In both cases the higher

\footnotetext{
${ }^{4}$ The inclusion of housing costs in the denominator causes an deviation from this definition.

${ }^{5}$ It is noteworthy that this increased variation in index is not the product of the particular normalisation used. For example, we find a similar gap between the standard deviations of log expenditures per capita; 0.52 for 1953/4 and 0.58 for 1961.
} 
1961 variance could be related to differences in the nature of the surveys, but also could be related to actual population changes. ${ }^{6}$

On household structure, A-S\&T acknowledged that the proportions of small households, containing only one or two people, had increased in the population of the period (1965: p.60). They also noted this growth was associated with an increase in the number of elderly heads of households and hypothesised this was part of the explanation of their finding of rising poverty.

This higher proportion of small households in the 1961 FES is notable, as can be seen in Table 9. In both samples, poverty incidence is high among one- and two-person households and the share of these households grows from $38.5 \%$ in 1953-4 HES to $44.1 \%$ in 1961 FES. Following on from this, in the 1961 FES data, $65 \%$ of all one-person and $47 \%$ of all twoperson households have heads of household aged over 60 years. The potential importance for measured poverty of this shift to smaller households can be calibrated by a simple shift-share analysis of the statistics in Table 9. Of the 3.7 percentage points increase that we find in the poverty rate between the $1953 / 4$ and 1961 data sets, approximately 3.1 points is due to changes in poverty rates among, and incidences of, one and two-person households, of which 1.95 points is due to greater proportion of these households in the 1961 data. In other words the greater share of small households accounts for over half the measured rise in poverty.

\section{$<$ Insert Table 9 about here $>$}

A-S\&T were also concerned that both the 1953/4 HES and 1960 FES surveys under-reported these households, but that under-reporting was probably greater for 1953/4 HES. This would have exaggerated their finding of increased poverty in 1960. We investigated this by studying the reports of the 1951 and 1961 censuses, ${ }^{7}$ to find the distributions of household by numbers of persons in the census. These are compared with the HES and FES proportions in Table 10. The differences between sample and census proportions are quite minor. Reweighting our expenditure-based poverty estimates to reflect the census distributions of household

\footnotetext{
${ }^{6}$ There is further potential statistical issue that might bear upon our poverty calculations. This lies in the difference in expenditure data collection between the two surveys. In the 1953/4 FES three weeks of spending were collected and in the 1961 FES the spending diaries spanned only two weeks. If averaging over a larger amount of weeks reduced the noisy transient expenditure component then part of the increased expenditure variance and thus potentially, part of the estimated poverty increase could be due to this effect. The size of the effect essentially depends upon the importance of the transient component in determining the cross-section variance of household expenditure. In an attempt to assess potential magnitude of this effect, we estimated the standard deviation of log household expenditure per capita for four single-week expenditure enquiries taken in the UK in 1937/8 and also for the average of the four quarters.(add ref). We found that the standard deviation of the four-week average, of 0.51 , was three log points below the average of the four one-week standard deviations, 0.54. This is a lot smaller that the difference we found between the 1953/4 and 1961 surveys, so that this effect, must, again only play a minor role, reducing our estimate of the difference on poverty rates a little more.
}

\footnotetext{
${ }^{7}$ General Register Office Census 1951 England and Wales, Housing Report, London HMSO, 1956, Table G; General Register Office Edinburgh, Census 1951 Scotland, Volume III, General Volume, Edinburgh HMSO, 1954, Table 42; General Register Office, Census 1961, Housing Tables, London HMSO, 1964-5, Table 10; General Register Office, Census 1961 Scotland Volume 4 Housing and Households, part II, Household Composition Tables, HMSO, 1966, Table 5.
} 
compositions changes the estimates only slightly. For the 1953-4 HES the poverty rate rises from 10.1 to 10.2 , whereas, for the 1961 FES the poverty rate falls from 13.8 to 13.4. An important part of the relatively small rise of poverty we find between 1953/4 and 1961 is an increase in the preponderance of small households in which poor and elderly inhabitants tended to dwell. Once we have corrected for under-and over-representation of these groups, our revised estimate is a rise in poverty from 10.2 to 13.4 per cent between 1953/4 and 1961 .

\section{$<$ Insert Table 10 about here $>$}

In summary, moving to a comparison of expenditure-based measures, and correcting for sampling biases in the distributions of households by numbers of people, reduces the difference in measured poverty rates considerably. Recall that A-S\&T found an increase of 7.8 percentage points, from 10.1 on 1953-4 HES to 17.9 in 1960 FES. We now find an expenditure-based percentage point increase of only 3.2 percentage points.

A further point of note is that our recalculations also reduce, very heavily, the estimated rise in the headcount poverty rate. A-S\&T found $7.0 \%$ and $14.2 \%$ of people living below $140 \%$ of their National Assistance poverty standard respectively on the 1953-4 and 1960 surveys. Our calculations using their expenditure measure, reduce this increase. We find headcount rates of $7.2 \%$ and $9.4 \%$, respectively in the $1953-4$ and 1961 data sets.

So far we employed A-S\&T's poverty lines, in order to re-work their analysis, but these lines, as we have noted, neither reflect a common absolute standard of living, nor a common relative standard of living. How much change was there in absolute and relative poverty between to two data sets? To find out, we (a) inflate the A-S\&T poverty line for 1953/4 by the rate of consumer price inflation from then to 1961, and apply that standard to the 1961 data and (b) inflate the same line by the rate of mean nominal household expenditure increase (capturing both real and nominal increases) between to the two dates. These two new standards allow us to make a consistent comparison between the two surveys.

\section{$<$ Insert Table 11 about here $>$}

The results, in Table 11, are striking. We estimate a small increase in absolute poverty, but a very large increase in relative poverty, which for 1961 is measured to affect almost onequarter of all households. Clearly, then, A-S\&T were right to highlight the increase in inequality at the low end of the household expenditure distribution. We have already remarked this increase seems related to a marked rise in the preponderance of one and two person households.

Alongside the increase in smaller households is a very likely increase in household populated by the elderly. Age data were not collected for the 1953/4 HES, but there were questions about retirement status. In the 1961 FES there were questions about receipt of pensions. Grouping the replies to these questions to create a 'retired' group of households for 1953/4 and a 'pensioner' group of households for 1961, we find $11 \%$ of 1953/4 households were 'retired' and 22\% of 1961 households were 'pensioners'. This is suggestive of a large increase in the retired population of households, coming about from increasing longevity 
and/or an increased propensity of the elderly to live independently. The measured poverty (using A-S\&T's expenditure measure) of these groups is striking. $43.9 \%$ of the retired in 1953/4 were in poverty, and 62.5\% of the pensioner households of 1961 were poor. Indeed ALL the A-S\&T poor expenditure households in the 1961 data were pensioner households and $48 \%$ of poor households in 1953/4 were retired households.

GB Census data confirm the growth in numbers of people aged over 64 in the population. Between the 1951 and 1961 Censuses, the proportion of over-64s grew from $11.0 \%$ to $11.9 \%$, and that in a baby-boom period of rapid population growth. But the key to understanding the differences in expenditure distributions between the expenditure surveys is to know how these people were arranged into households. Unfortunately the Census Reports for 1951 and 1961 collate household information by age and by numbers of members quite differently, so we can make only an imperfect comparison. On age, the 1951 Census Report (General Register Office, 1952, Table V.1, p 162) lists households by the age of the self-nominated head of household, while the 1961 Report (General Register Office, 1966, Table 1, p 2) list households by the age of the 'Chief Economic Supporter'. On numbers of household members the 1951 Report lists by number of persons, while the 1961 Report uses a much more complex categorisation, taking into account the presence of married couples, ancestors (of the Chief Economic Supporter), servants etc., but not giving numbers of people, except for single member households. Thus the only clean comparison is with respect to singleperson households. In 1951 10.7\% of households contained only one person, and 4.7\% of all households contained a single person aged over 60 years. In 1961 11.9\% of household contained only one person, and $7.4 \%$ of all households were either a single man over 65 or a single woman over 60 . It should be noted that the vast majority of these were single women, 85\% in 1961 for instance. So, there was a growing proportion of small, elderly households.

A final part of the story might be a rise of variation within the retired/pensioner households. If we look at the difference in terms of per adult male equivalised expenditure between households headed by a retired person and those not headed by a retired person we find the retired mean is very close to $70 \%$ of the mean for non-retired in the 1953/4 data. Similarly, among households in 1961, the same mean for pensioner households is about $74 \%$ of that for non-pensioner households. Importantly, however, the coefficient of variation of equivalised for retired households in 1953/4 is 0.67, much lower that the same measure for pensioner households in 1961, where we find it to be 0.91 . Thus, not only has this low expenditure group almost surely expanded, but there seems to have been an increase in within-group variance as well.

So far we have two proximate determinants, or correlates, of measured poverty, retirement, or old age, and small households, whose growth in importance relates to the rise on poverty and inequality between the surveys. In Table 12 we present log equivalised expenditure regression for both data sets.. Both results show small households and those headed by either retired or pensioner heads are much more likely to be A-S\&T expenditure-poor. The result also indicates that controlling for household size and pensioner/retirement status does not eliminate the large differential in expenditure variance between the two samples. 


\section{Conclusion}

We have shown that A-S\&T's estimate of the rise in poverty was exaggerated by (a) comparing expenditure with income poverty rates and (b) using poverty lines whose relationship reflected something between a relative and an absolute comparison. In absolute poverty terms A-S\&T overestimated the rise, which we estimate at less than one percentage point. If relative poverty had been their concern, then they underestimated the rise. Comparing the samples with census information to judge representativeness, something AS\&T were worried, has only a minor effect on estimates of poverty.

However, what was driving their results was a large rise in household expenditure inequality, importantly associated with, but by no means fully explained by, the emergence of the pensioner household. As we have seen, the preponderance of retired/pensioner households almost certainly increased and the increase in expenditure variance happened within the pensioner group as well as more widely.

In giving an answer to the question of whether A-S\&T were right in their poverty estimation, we uncover deeper questions of the causes of the rise in household equivalised expenditure inequality and of the rise in small, elderly households. Our present view is that our data cannot answer those new questions, but they and new questions for the 1950s and have resonance today.

\section{References}

Abel-Smith, B. and P. Townsend (1965) The poor and the poorest, A New Analysis of the Ministry of Labour's Family Expenditure Surveys of 1953-54 and 1960, G.Bell \& Sons Ltd., York House, Portugal Street, London, W.C.2.

Deaton, A. (1997) The Analysis of Household Surveys: A Microeconometric Approach to Development Policy, World Bank, Washington. 
Chart 1 The distribution of expenditure relative to poverty standard, HES 1953-4

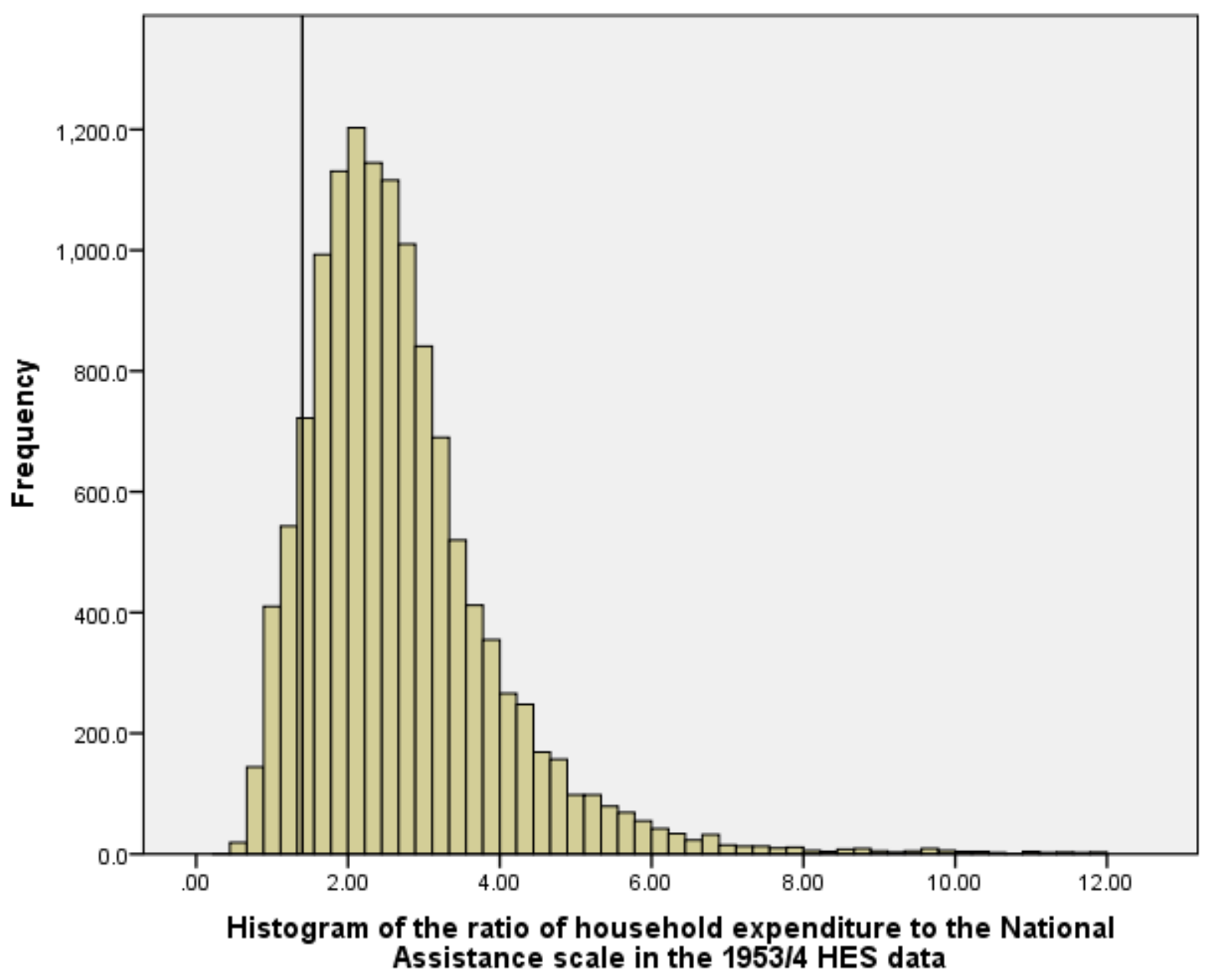

Source, Authors' calculations, see text.

Chart 2 The distribution of expenditure relative to poverty standard, FES 1961 


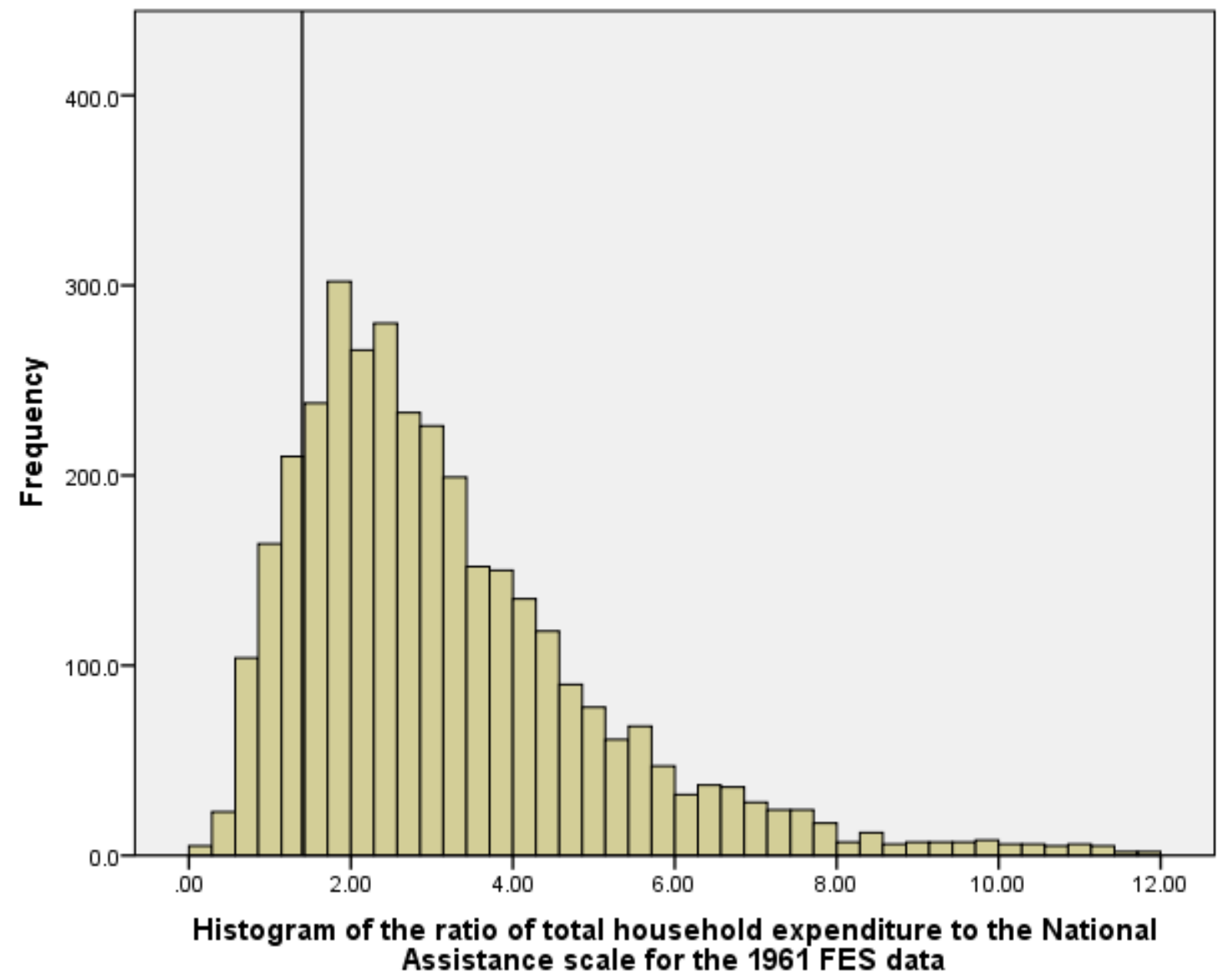

Source, Authors' calculations, see text. 
Table 1: Abel-Smith and Townsend's sample from the 1953/4 survey:

\begin{tabular}{|c|c|c|c|c|c|c|c|}
\hline & \multicolumn{7}{|c|}{ Weekly Income of Household } \\
\hline \multirow{7}{*}{ 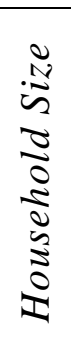 } & & $£ 14-20$ & $£ 10-14$ & $£ 8-10$ & $£ 6-8$ & $£ 3-6$ & Under $£ 3$ \\
\hline & 1 & & & & 151 & 337 & 635 \\
\hline & 2 & & & & 590 & 721 & 103 \\
\hline & 3 & & & 566 & 388 & 131 & 8 \\
\hline & 4 & & & 453 & 194 & 57 & 1 \\
\hline & 5 & & 360 & 183 & 73 & 27 & \\
\hline & $6+$ & 288 & 236 & 84 & 41 & 6 & \\
\hline
\end{tabular}

Total: 5633

From these 5633 households they then took a 25\% sample:

\begin{tabular}{|c|c|c|c|c|c|c|c|}
\hline & \multicolumn{7}{|c|}{ Weekly Income of Household } \\
\hline \multirow{7}{*}{ 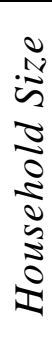 } & & $£ 14-20$ & $£ 10-14$ & $£ 8-10$ & $£ 6-8$ & $£ 3-6$ & Under $£ 3$ \\
\hline & 1 & & & & 38 & 84 & 158 \\
\hline & 2 & & & & 147 & 180 & 26 \\
\hline & 3 & & & 142 & 96 & 33 & 2 \\
\hline & 4 & & & 113 & 48 & 15 & \\
\hline & 5 & & 90 & 46 & 18 & 7 & \\
\hline & $6+$ & 72 & 59 & 21 & 11 & 2 & \\
\hline
\end{tabular}

Total: 1408

Source: Poor and Poorest Appendix 3, Tables 1 and 2, page 73. 
Table 2: Number and percentage of households and persons with low expenditures

\begin{tabular}{c|c|c|c|c|c|c}
\hline \multirow{2}{*}{$\begin{array}{c}\text { Total } \\
\text { expenditure }\end{array}$} & \multicolumn{3}{|c|}{ Households } & \multicolumn{2}{c|}{ Persons } & $\begin{array}{c}\text { Estimate of } \\
\text { total } \\
\text { as \% of basic } \\
\text { national }\end{array}$ \\
\cline { 2 - 5 } No. & $\%$ & $\begin{array}{c}\text { Average } \\
\text { size }\end{array}$ & No. & $\%$ & $\begin{array}{c}\text { number of } \\
\text { persons in }\end{array}$ \\
assistance scale & & & & & & UK \\
plus & & & & & & (thousands) \\
rent/housing & & & & & & \\
\hline Under 80 & 17 & 0.5 & 1.5 & 26 & 0.3 & 152 \\
$80-89$ & 18 & 0.6 & 1.3 & 23 & 0.2 & 101 \\
$90-99$ & 33 & 1 & 2.3 & 75 & 0.7 & 354 \\
$100-109$ & 61 & 1.9 & 2.4 & 149 & 1.4 & 709 \\
$110-119$ & 54 & 1.7 & 2.6 & 144 & 1.4 & 709 \\
$120-129$ & 64 & 2 & 2.9 & 178 & 1.8 & 911 \\
$130-139$ & 79 & 2.4 & 2.7 & 210 & 2 & 1012 \\
$140-159$ & 162 & 5 & 3.2 & 525 & 5.1 & 2581 \\
160 and over & 2737 & 84.9 & 3.3 & 8940 & 87.1 & 44082 \\
\hline
\end{tabular}

Source: Poor and Poorest, Table 3, page 28. 
Table 3: Number of households with low expenditure (and all households in subsample)

\begin{tabular}{|c|c|c|c|c|c|c|c|}
\hline & \multicolumn{7}{|c|}{ Weekly Income of Household } \\
\hline \multirow{7}{*}{ 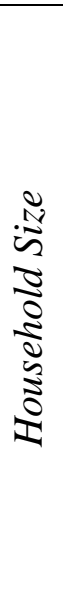 } & & Under $£ 3$ & $£ 3-6$ & $£ 6-8$ & $£ 8-10$ & $£ 10-14$ & $£ 14-20$ \\
\hline & 1 & 108 (159) & $17(84)$ & $1(38)$ & $-(23)$ & $-(15)$ & - (5) \\
\hline & 2 & $13(26)$ & 70 (180) & $5(147)$ & - (163) & $-(226)$ & $-(122)$ \\
\hline & 3 & $0(2)$ & $16(33)$ & $14(97)$ & $9(141)$ & $-(260)$ & - (193) \\
\hline & 4 & $0(0)$ & $9(14)$ & $12(49)$ & $8(113)$ & - (206) & - (155) \\
\hline & 5 & 0 & $5(7)$ & $6(18)$ & $5(46)$ & $1(90)$ & - (96) \\
\hline & $6+$ & 0 & $1(1)$ & $5(10)$ & $10(21)$ & $8(59)$ & $3(72)$ \\
\hline \multicolumn{2}{|c|}{ All sizes } & $121(187)$ & 118 (319) & 43 (359) & $32(507)$ & $9(856)$ & $3(643)$ \\
\hline
\end{tabular}

Source: Poor and the Poorest, Table 2, page 27. 
Table 4: 1953/4 Household Expenditure Survey (entire survey)

\begin{tabular}{l|l|l}
\hline & All Households & $\begin{array}{l}\text { Households with children } \\
\text { under 16 years old }\end{array}$ \\
\hline $\begin{array}{l}\text { Average number of Adults and } \\
\text { Adolescents (over 16 years) }\end{array}$ & 2.29 & 2.38 \\
Average number aged 5-15 & 0.59 & 1.26 \\
Average number under 5 & 0.29 & 0.63 \\
Average total expenditure & $£ 139 \mathrm{~s} 4 \mathrm{~d}$ & $£ 14$ 16s 9d \\
Average housing costs & $16 \mathrm{~s} 7 \mathrm{~d}$ & $17 \mathrm{~s} 0 \mathrm{~d}$ \\
Sample & 12857 & 6003 \\
& & \\
Where income is reliably reported & $£ 123 \mathrm{~s} 4 \mathrm{~d}$ & \\
Average income & $£ 13$ ss 5d & \\
Average total expenditure & 12252 & \\
Sample & S & \\
\hline
\end{tabular}

Source: authors' calculations from 1953/4 full survey 
Table 5: Household and head of household characteristics and poverty rates

\begin{tabular}{|c|c|c|c|}
\hline & $\%$ of the poor & $\%$ of all & $\begin{array}{c}\text { \% poverty } \\
\text { rate }\end{array}$ \\
\hline \multicolumn{4}{|l|}{ By adults in household } \\
\hline Single Man & 7.9 & 2.6 & 30.5 \\
\hline Single Woman & 37.4 & 9.5 & 39.6 \\
\hline Couple & 40.8 & 63.6 & 6.4 \\
\hline All other & 13.9 & 24.3 & 5.8 \\
\hline \multicolumn{4}{|l|}{ By occupation of household head } \\
\hline No gainful employment & 72.3 & 20.3 & 35.8 \\
\hline Manual employee & 22.1 & 52.7 & 4.2 \\
\hline Own account non-professional & 3.3 & 5.6 & 5.8 \\
\hline Clerical & 1.2 & 8.0 & 1.6 \\
\hline \multicolumn{4}{|l|}{ By labour market status of household head } \\
\hline Out of the labour force & 72.3 & 20.2 & 33.8 \\
\hline Unemployed & 3.0 & 0.9 & 28.9 \\
\hline On sick leave & 5.2 & 2.3 & 22.2 \\
\hline At work & 19.5 & 76.5 & 2.4 \\
\hline \multicolumn{4}{|l|}{ By household size } \\
\hline One & 39.8 & 10.2 & 39.3 \\
\hline Two & 34.0 & 28.3 & 12.1 \\
\hline Three & 8.4 & 24.9 & 3.4 \\
\hline Four & 5.8 & 19.6 & 3.0 \\
\hline Five & 5.3 & 9.8 & 5.4 \\
\hline Six & 3.0 & 4.0 & 7.7 \\
\hline Seven or more & 3.7 & 3.2 & 11.5 \\
\hline
\end{tabular}

Source: authors' calculations from 1953/4 full survey 
Table 6: National Assistance weekly scale rates other than rent.

\begin{tabular}{l|c|c|c|c}
\hline Effective from: & \multicolumn{2}{|c|}{$16^{\text {th }}$ June 1952} & \multicolumn{2}{c}{$3^{\text {rd }}$ April 1961 } \\
\hline Ordinary rate: & Pence (d.) & Single adult \% & Pence (d.) & Single adult \% \\
Husband and wife & 708 & 169 & 1080 & 168 \\
Single householder & 420 & 100 & 642 & 100 \\
For other persons: & & & & \\
$\quad$ aged 21 or over & 372 & 89 & 594 & 93 \\
aged 18-20 & 312 & 74 & 486 & 71 \\
aged 16-17 & 258 & 61 & 384 & 60 \\
aged 11-15 & 192 & 46 & 288 & 45 \\
aged 5-10 & 162 & 39 & 240 & 37 \\
aged under 5 & 132 & 31 & 204 & 32 \\
\hline
\end{tabular}

Source: Lynes, 1961, Appendix 1, page 50. 
Table 7: Descriptive statistics for total household expenditures and poverty standards

\begin{tabular}{l|c|c|c|c}
\hline & \multicolumn{2}{|c|}{ 1953-4 HES } & \multicolumn{2}{c}{ 1961 FES } \\
Mean (d.) & $\begin{array}{c}\text { Total weekly } \\
\text { expenditure } \\
\text { Median (d.) }\end{array}$ & $\begin{array}{c}\text { Poverty } \\
\text { standard } \\
\text { SD of log }\end{array}$ & $\begin{array}{c}\text { Total weekly } \\
\text { expenditure }\end{array}$ & Poverty standard \\
$90 / 10$ & 2804 & 1157 & 7589 & 2395 \\
$50 / 10$ & 0.62 & 0.34 & 6325 & 2211 \\
\hline Gini coefficients & 2.33 & 0.70 & 0.39 \\
Average weekly expenditure per capita & 1.59 & 5.44 & 2.25 \\
Weekly income per capita & $1953-4$ HES & 1961 FES \\
Weekly expenditure per equivalent adult & 29.4 & 33.2 \\
Weekly income per equivalent adult & 28.8 & -2.66 \\
\hline Notes: All equivalence scales are per married couple. Author's calculations, except for *, \\
which is taken from the supplement to the IFS Report, Jonathan Cribb, Andrew Hood, \\
Robert Joyce and David Phillips "Living Standards, Poverty and Inequality in the UK: 2013', \\
IFS, London, 2013
\end{tabular}


Table 8 New estimates of NA standard household poverty rates, \%.

\begin{tabular}{l|c|c|c|}
\hline & 1953/4 HES & 1960 FES & 1961 FES \\
\hline Expenditure-based, full sample & 10.1 & & 13.8 \\
Income-based, restricted sample & 15.3 & & \\
Income-based, full sample & 10.3 & 17.9 & \\
Expenditure-based restricted sample & 10.9 & \\
\hline
\end{tabular}

Source: Authors' calculations, except 1960 FES from Abel-Smith and Townsend. The 1953/4 restricted sample contains only cases where the two income indicators in the data set are mutually consistent. 
Table 9: Expenditure-based A-S\&T poverty rates by size of household

\begin{tabular}{l|c|c|c|c}
\hline & \multicolumn{2}{|c|}{ 1953-4 HES } & \multicolumn{2}{c}{ 1961 FES } \\
\hline $\begin{array}{l}\text { Number of persons } \\
\text { in household }\end{array}$ & Poverty rate & Share of sample & Poverty rate & Share of sample \\
\hline 1 & 39.3 & 10.2 & 43.0 & 14.2 \\
2 & 12.1 & 28.3 & 14.9 & 29.9 \\
3 & 3.4 & 24.9 & 5.7 & 22.3 \\
4 & 3.0 & 19.6 & 4.6 & 18.6 \\
5 & 5.4 & 9.8 & 7.2 & 8.4 \\
6 & 7.7 & 4.0 & 7.8 & 3.7 \\
7 & 8.9 & 1.8 & 5.6 & 1.6 \\
8 or more & 14.9 & 1.4 & 8.0 & 1.4 \\
\hline
\end{tabular}

Source, Authors' calculations, see text. 
Table 10 Percentages of households by size in the HES, FES and Censuses.

\begin{tabular}{l|c|c|c|c}
\hline $\begin{array}{l}\text { Number of persons } \\
\text { in household }\end{array}$ & $\begin{array}{c}\text { GB 1951 } \\
\text { Census }\end{array}$ & 1953-4 HES & $\begin{array}{c}\text { GB 1961 } \\
\text { Census }\end{array}$ & 1961 FES \\
\hline 1 & 10.5 & 10.2 & 13.1 & 14.2 \\
2 & 26.8 & 28.3 & 29.3 & 29.9 \\
3 & 24.9 & 24.9 & 22.9 & 22.3 \\
4 & 19.1 & 19.6 & 18.5 & 18.6 \\
5 & 9.9 & 9.8 & 9.1 & 8.4 \\
6 & 4.9 & 4.0 & 4.0 & 3.7 \\
7 & 2.1 & 1.8 & 1.7 & 1.6 \\
8 or more & 1.7 & 1.4 & 1.4 & 1.4 \\
\hline
\end{tabular}

Source, Authors' calculations, see text. 
Table 11: Estimating changes in absolute and relative poverty rates(\%), 1953/4 HES1961 FES

\begin{tabular}{l|c|c}
\hline & 1953/4 HES & 1961 FES \\
\hline Expenditure-based, RPI adjusted & 10.1 & 10.9 \\
Expenditure-based, nominal expenditure adjusted & 10.1 & 24.3 \\
\hline
\end{tabular}

Source: Author's calculations 
Table 12 Estimating the impacts of household size and pensioner/ retirement status in equivalised income 1953/4 and 1961.

Dependent variable log(expenditure/A-S\&T poverty line)

\begin{tabular}{l|c|c}
\hline Explanatory variables & $1953 / 4$ HES & 1961 FES \\
\hline Household size & $0.124(13.4)$ & $0.233(10.9)$ \\
Household size squared & $-0.017(14.9)$ & $-0.024(9.4)$ \\
Pensioner household & & $-0.271(10.9)$ \\
Retired household & $-0.383(29.9)$ & \\
& & \\
$\mathrm{R}^{2}$ & 0.10 & 0.100 \\
Standard error & 0.43 & 0.60 \\
Sample size & 12803 & 3466 \\
\hline
\end{tabular}




\section{Appendix 1: Poverty Lines:}

Abel Smith and Townsend constructed 2 different poverty lines. The first was to identify the number of households whose expenditure less income tax and national insurance totalled less than $140 \%$ of National Assistance rates plus weekly expenditure on housing (rent, repairs, mortgage, etc). They adapted the National Assistance rates to align with the age ranges used in the 1953-4 Enquiry:

\section{Adapted National Assistance Rates}

\begin{tabular}{|l|l|l|}
\hline & s & d \\
\hline Husband and wife & 59 & 0 \\
\hline Single householder & 35 & 0 \\
\hline Others 21 or over & 31 & 0 \\
\hline $16-21$ & 23 & 9 \\
\hline $5-16$ & 14 & 9 \\
\hline Under 5 & 11 & 0 \\
\hline
\end{tabular}

The second poverty line they used was the 1950 Rowntree-Lavers line, recalculated at July 1953 prices:

\begin{tabular}{|c|c|c|c|}
\hline Composition of household & $\begin{array}{l}\text { No. of persons in } \\
\text { household }\end{array}$ & $S$. & $d$. \\
\hline \multicolumn{4}{|l|}{ Adults only, one sex } \\
\hline $1 \mathrm{man}$ & 1 & 47 & 5 \\
\hline 1 woman & 1 & 42 & 1 \\
\hline 2 men & 2 & 71 & 2 \\
\hline 2 women & 2 & 68 & 8 \\
\hline 3 men & 3 & 94 & 11 \\
\hline 3 women & 3 & 88 & 11 \\
\hline \multicolumn{4}{|l|}{ Adults only, both sexes } \\
\hline 1 man, 1 woman & 2 & 70 & 2 \\
\hline 2 men, 1 woman & 3 & 94 & 0 \\
\hline 1 man, 2 women & 3 & 90 & 1 \\
\hline 2 men, 2 women & 4 & 113 & 10 \\
\hline 3 men, 1 woman & 4 & 117 & 8 \\
\hline 1 man, 3 women & 4 & 113 & 6 \\
\hline \multicolumn{4}{|l|}{ One adult and children } \\
\hline 1 man, 1 child & 2 & 64 & 11 \\
\hline 1 man, 2 children & 3 & 82 & 5 \\
\hline 1 man, 3 children & 4 & 103 & 1 \\
\hline 1 woman, 1 child & 2 & 60 & 10 \\
\hline
\end{tabular}




\begin{tabular}{|c|c|c|c|}
\hline 1 woman, 2 children & 3 & 78 & 11 \\
\hline 1 woman, 3 children & 4 & 97 & 0 \\
\hline 1 woman, 4 children & 5 & 115 & 0 \\
\hline \multicolumn{4}{|l|}{ Two adults and children } \\
\hline 1 man, 1 woman, 1 child & 3 & 88 & 8 \\
\hline 1 man, 1 woman, 2 children & 4 & 110 & 1 \\
\hline 1 man, 1 woman, 3 children & 5 & 127 & 11 \\
\hline 1 man, 1 woman, 4 children & 6 & 146 & 0 \\
\hline 2 women, 1 child & 3 & 87 & 10 \\
\hline 2 women, 2 children & 4 & 105 & 11 \\
\hline 2 women, 3 children & 5 & 123 & 11 \\
\hline \multicolumn{4}{|l|}{ Three adults and children } \\
\hline 2 men, 1 woman, 1 child & 4 & 112 & 5 \\
\hline 2 men, 1 woman, 2 children & 5 & 130 & 5 \\
\hline 2 men, 1 woman, 3 children & 6 & 147 & 8 \\
\hline 1 man, 2 women, 1 child & 4 & 112 & 0 \\
\hline 1 man, 2 women, 2 children & 5 & 130 & 7 \\
\hline 1 man, 2 women, 3 children & 6 & 148 & 5 \\
\hline 3 women, 1 child & 4 & 108 & 4 \\
\hline 3 women, 2 children & 5 & 126 & 5 \\
\hline 3 women, 3 children & 6 & 144 & 6 \\
\hline \multicolumn{4}{|l|}{ Four adults and children } \\
\hline 1 man, 3 women, 1 child & 5 & 132 & 7 \\
\hline 1 man, 3 women, 2 children & 6 & 151 & 2 \\
\hline 2 men, 2 women, 1 child & 5 & 132 & 3 \\
\hline 2 men, 2 women, 2 children & 6 & 150 & 4 \\
\hline 2 men, 2 women, 1 children & 7 & 173 & 0 \\
\hline 3 men, 1 woman, 1 child & 5 & 136 & 2 \\
\hline 3 men, 1 woman, 2 children & 6 & 154 & 2 \\
\hline \multicolumn{4}{|l|}{ Additional persons } \\
\hline $1 \mathrm{man}$ & & 23 & 9 \\
\hline 1 woman & & 20 & 3 \\
\hline 1 child & & 18 & 1 \\
\hline
\end{tabular}




\section{Appendix 2: Assumptions about Household Composition:}

In the 1953/4 HES the exact composition of each household is not available for all households. Householders recorded themselves as either single adults, married couples or 'other'. For all households the numbers of children under 16 years and of children under 5 years are recorded. For the 'other' category only the number of people over 16 years is known, that is, no breakdown id given of those over and under 21 years. Abel Smith and Townsend therefore made the following assumptions about households assigned to this category:

\begin{tabular}{|c|c|c|c|c|}
\hline $\begin{array}{l}\text { Household } \\
\text { Size }\end{array}$ & $\begin{array}{l}\text { All children } \\
\text { under } 16\end{array}$ & $5-16$ & $0-5$ & Assumptions about persons other than children \\
\hline 2 & 0 & & & Assumed both over 21 \\
\hline \multirow[t]{2}{*}{3} & 1 & & & Assumed both over 21 \\
\hline & 0 & & & Couple plus 1 adult \\
\hline \multirow[t]{5}{*}{4} & 0 & & & Couple, one person over 21 , one person $18-21$ \\
\hline & 1 & & & Couple, one person over 21 , one person $18-21$ \\
\hline & 2 & 2 & 0 & One person over 21 , one person $16-18$ \\
\hline & 2 & 1 & 1 & Assumed both over 21 \\
\hline & 2 & 0 & 2 & Assumed both over 21 \\
\hline \multirow[t]{4}{*}{5} & 0 & & & $\begin{array}{l}\text { Couple, one person over } 21 \text {, one person } 18-21 \text {, } \\
\text { one person } 16-18\end{array}$ \\
\hline & 1 & & & Couple, one person over 21 , one person $18-21$ \\
\hline & 2 & & & Couple, one person over 21 \\
\hline & 3 & & & Assumed both over 21 \\
\hline \multirow[t]{6}{*}{6} & 1 & & & $\begin{array}{l}\text { Couple, one person over } 21 \text {, one person } 18-21 \text {, } \\
\text { one person } 16-18\end{array}$ \\
\hline & 2 & 2 & & Couple, one person over 21 , one person $18-21$ \\
\hline & 2 & 1 & 1 & Couple, two persons over 21 \\
\hline & 2 & & 2 & Couple, two persons over 21 \\
\hline & 3 & & & Couple, one person over 21 \\
\hline & 4 & & & Assumed both over 21 \\
\hline \multirow[t]{4}{*}{7} & 2 & 1 & 1 & Couple, two persons over 21 , one person $16-18$ \\
\hline & 3 & 3 & 0 & Couple, one person over 21 , one person $16-18$ \\
\hline & 3 & 0 & 3 & Couple, two persons over 21 \\
\hline & 4 & 3 & 1 & Couple, one person over 21 \\
\hline 8 & 5 & 3 & 2 & Couple, one person over 21 \\
\hline 9 & 4 & 4 & & Two couples, one person $16-18$ \\
\hline
\end{tabular}

However, with the full 1953 data set at our disposal, we have additional household types, so we make assumptions in line with those of A-S\&T in this 'other' category. Also since we have no way of distinguished 16-18 year olds from 18-21 years olds for any households, we follow A-S\&T and assign an average National Assistance rate for all in, or assumed to be in, the 16-21 age range. 